\title{
МЕСТО И РОЛЬ РЕШЕНИЙ ЕВРОПЕЙСКОГО СУДА ПО ПРАВАМ ЧЕЛОВЕКА В МЕХАНИЗМЕ УДАЛЕНИЯ ПРОБЕЛОВ В УГОЛОВНО-ПРОЦЕССУАЛЬНОМ ПРАВЕ РОССИИ
}

\author{
Н. О. Овчинникова \\ Саратовская государственная юридическая академия
}

Поступила в редакцию 30 августа 2020 г.

Аннотация: Россия остается абсолютныл лидерол по числу жалоб, поданных в Европейский суд по правал человека (ЕСПЧ), что следует из статистического отчета за 2019 г. на сайте Суда. К кониу 2019 г. на расслотрении ЕСПЧ находилось 59800 обращений, больще четверти (15 050) приходилось на долю России - это число рекордное за последние сель лет. В первую тройку по количеству поданных жалоб вошли также Туриия (9250 жалоб) и Украина (8850). За последние 20 лет работы ЕСПЧ с Российской Федерации была взыскана сулми в разлере 1,95 млрд евро. Эксперты объясняют подобную диналику проблемали российской правовой систель. Указанная статистика обязывает обратиться к вопросал влияния решений ЕСПЧ на национальное законодательство Российской Федераиии и на уголовно-процессуальное законодательство в частности, поскольку 2/3 жалоб, поступающих от российских граждан, направлень на защиту нарушенных прав иленно в сфбере уголовного судопроизводства. Со слов главного редактора журнала "Бюллетень ЕСПЧ" Юрия Берестнева, в настоящее время наблюдается массовая подача жалоб на условия содержания под стражей и на задержания на митингах и пикетах. Данное исследование позволит определить место решений ЕСПЧ в системе источников уголовно-процессуального права России; выявить место и роль решений ЕСПЧ в механизме удаления пробелов в уголовно-процессуальнол праве России; описать влияние Конституционного Суда РФ на исполнение решений ЕСПЧ и их дальнейшую илплементацию в национальное уголовно-процессуальное законодательство.

Ключевые слова: пробел, устранение пробела, преодоление пробела, судебная конституционная норла, механизл удаления пробелов, уголовное судопроизводство, Европейский суд по правам человека, решение ЕСПЧ, Конституционный Суд РФ.

Abstract: Russia remains the absolute leader in the number of complaints filed with the European Court of Human Rights (ECHR), which follows from the statistical report for 2019 on the Court's website. By the end of 2019, 59,800 applications were pending before the ECHR, more than a quarter $(15,050)$ accounted for by Russia - this is a record number over the past seven years. Turkey $(9,250$ complaints) and Ukraine $(8,850)$ are also in the top three in terms of the number of complaints filed. Over the past 20 years of the ECHR's work, an amount of 1.95 billion euros has been collected from the Russian Federation. Experts explain this dynamics by the problems of the Russian legal system. These statistics oblige to address the issues of the impact of the decisions of the ECHR on the national legislation of the Russian Federation and on the criminal procedure legislation in particular, since $2 / 3$ of the complaints received from Russian citizens are aimed at protecting violated rights in the sphere of criminal procee-

(C) Овчинникова Н. О., 2021 
dings. According to the editor-in-chief of the ECHR Bulletin, Yuri Berestnev, there is currently a massive filing of complaints about the conditions of detention and about detentions at rallies and pickets. This study will help determine the place of the ECHR decisions in the system of sources of criminal procedure law in Russia; to identify the place and role of the decisions of the ECHR in the mechanism for removing gaps in the criminal procedure law of Russia; describe the influence of the Constitutional Court of the Russian Federation on the execution of the decisions of the ECHR and their further implementation in the national criminal procedure legislation.

Key words: gap, elimination of the gap, bridging the gap, judicial constitutional norm, mechanism for removing gaps, criminal proceedings, European Court of Human Rights, decision of the ECHR, Constitutional Court of the Russian Federation.

Механизм удаления пробелов в уголовно-процессуальном праве - это упорядоченная система юридических приемов и способов, позволяющих окончательно устранить пробел, который включает в себя следующие элементы (этапы): выявление (обнаружение) пробелов и установление причин их возникновения, устранение или преодоление пробелов и профилактика их возникновения. При этом конечный результат всегда должен выражаться в устранении пробела, даже после его неоднократного преодоления правоприменителем. Выявление пробелов осуществляется в ходе научно-исследовательской и правоприменительной деятельности. Устранение пробелов возможно только нормотворческим путем. Преодоление пробелов достигается путем толкования закона, применения аналогии закона и аналогии права. Способы проббилактики возникновения пробелов - это набор средств, направленных на предупреждение возникновения пробелов в уголовно-процессуальном праве и их минимизацию ${ }^{1}$.

Наглядно действие механизма удаления пробелов в уголовно-процессуальном праве отражено в следующей схеме (рисунок).

Определение места и роли решений ЕСПЧ в механизме удаления пробелов в уголовно-процессуальном праве целиком и полностью зависит от степени использования его правовых позиций законодателем в ходе нормотворческой деятельности и правоприменителем при разрешении конкретного уголовного дела.

Конвенция о защите прав человека и основных свобод 1950 г. (далее Конвенция), ратифицированная 30 марта 1998 г., в силу положений ч. 4 ст. 15 Конституции РФ и ч. 3 ст. 1 Уголовно-процессуального кодекса РФ 2001 г. (далее - УПК РФ) является источником уголовно-процессуального права и имеет высшую юридическую силу. В целях обеспечения должной реализации положений Конвенции был создан и действует ныне Европейский суд по правам человека (далее - ЕСПЧ), юрисдикция которого распространяется на все государства, ратифицировавшие Конвенцию, и

${ }^{1}$ См. подробнее: Овчиннникова Н. О. Пробелы в уголовно-процессуальном праве и способы их устранения и преодоления : авторед. дис. ... канд. юрид. наук. Саратов, 2017. С. 10-11; Ее же. Пробелы в уголовно-процессуальном праве России. М., 2018. С. 75-130. 


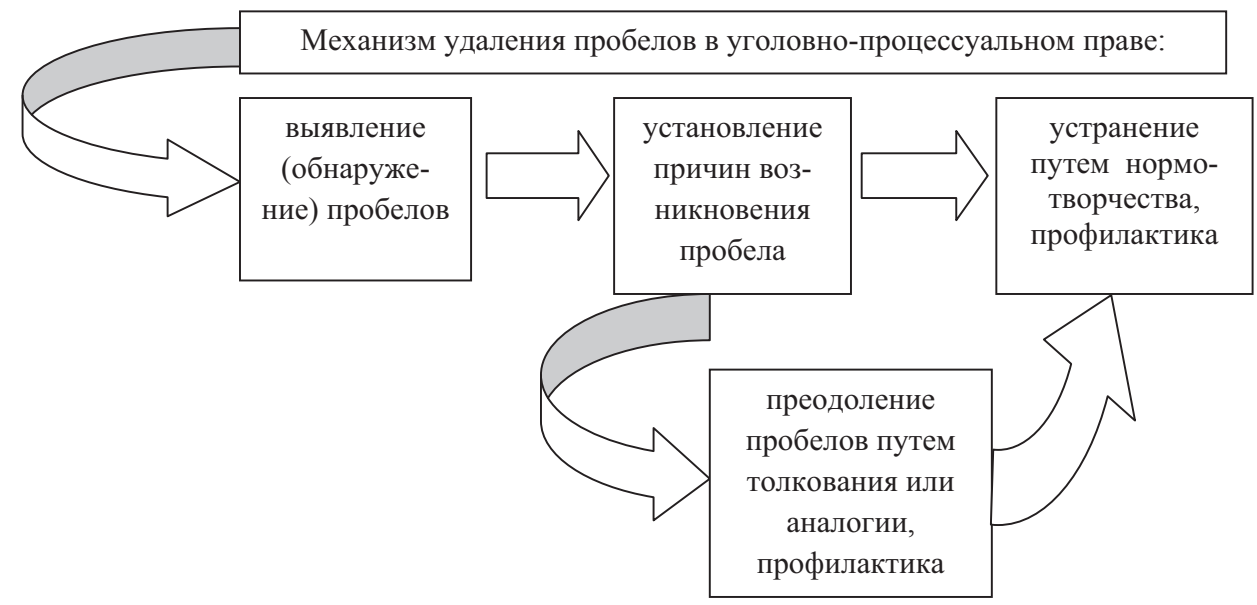

Рисунок. Механизм удаления пробелов в уголовно-процессуальном праве России

включает все вопросы, относящиеся к толкованию и применению Конвенции. Закономерным является вопрос о правовой природе решений ЕСПЧ - будут ли они источником уголовно-процессуального права. Решение Европейского суда по правам человека - «официально опубликованное решение, содержащее толкование общепризнанных принципов и международных норм о правах человека, Европейской конвенции о защите прав человека и основных свобод и Протоколов к ней, носящее общий характер и имеющее обязательную юридическую силу в уголовно-процессуальном праве Российской Федерации» ${ }^{2}$.

Любой участник уголовного судопроизводства вправе обратиться в ЕСПЧ за защитой своих нарушенных прав, охраняемых Конвенцией, когда все средства внутригосударственной защиты исчерпаны. В случае удовлетворения жалобы против России ЕСПЧ выносит постановление, обязательное для исполнения. На общеобязательность решений ЕСПЧ неоднократно обращалось внимание в правовых позициях Конституционного Суда РФ³ и в разъяснениях Пленума Верховного Суда РФ $\Phi^{4}$. Более

${ }^{2}$ Девятова О. В. Решения Европейского суда по правам человека в механизме уголовно-процессуального регулирования : автореф. дис. ... канд. юрид. наук. Ижевск, 2007. С. 12. См. также: Селина E. B. Реализация решений Европейского суда по правам человека в уголовном процессе Российской Федерации // Вестник РУДН. Серия: Юридические науки. 2011. № 4. С. 39-46 ; Ерлишина Н. С. Европейские стандарты в области прав человека и их роль в обеспечении прав личности в российском уголовном процессе : автореф. дис. ... канд. юрид. наук. Саратов, 2012 .

${ }^{3}$ По делу о проверке конституционности положений части первой ст. 47 и части второй ст. 51 УПК РСФСР в связи с жалобой гражданина В. И. Маслова : постановление Конституционного Суда РФ от 27 июня 2000 г. № 11-П // Собр. законодательства Рос. Федерации. 2000. № 27. Ст. 3881.

${ }^{4} \mathrm{O}$ применении судами общей юрисдикции общепризнанных принципов и норм международного права и международных договоров Российской Федерации : постановление Пленума Верховного Суда РФ от 10 октября 2003 г. № 5 (в ред. от 


\section{Вестник ВГУ. Серия: Право}

того, председатель Конституционного Суда РФ В. Д. Зорькин неоднократно подчеркивал, что прецеденты ЕСПЧ оцениваются Конституционным Судом РФ как источник права 5 .

Но позиция председателя Конституционного Суда РФ о природе решений ЕСПЧ с течением времени претерпела существенные изменения: если в 2006 г. она заключалась в том, что указанные решения должны оцениваться Конституционным Судом РФ как источник права ${ }^{6}$, то в настоящее время В. Д. Зорькин высказывается о двойных стандартах в деятельности ЕСПЧ и в его решениях ${ }^{7}$.

Исполнение решений ЕСПЧ и имплементащия содержащихся в них толковательных разъяснений Конвенции в уголовно-процессуальное законодательство вызывает существенные затруднения ввиду того, что отсутствует правовая регламентация указанной процедуры, а прецедентный характер решений не позволяет считать их источником российского права. Помимо этого не все постановления ЕСПЧ подлежат исполнению Российской Федерацией, поскольку Конституционный Суд РФ ввел некоторые ограничения их общеобязательности ${ }^{8}$. Постановление ЕСПЧ не мо-

05.03.2013) // Рос. газета. 2003. № 3358 ; Обзор практики межгосударственных органов по защите прав и основных свобод человека. 2019. № 2. URL: http://www. consultant.ru/document/cons_doc_LAW_327970/ (дата обращения: 13.08.2019).

${ }^{5}$ См.: Зорькин В. Д. На вершине судебной власти : интервью // ЭЖ-Юрист. 2006. № 41 ; Его же. Прецедентный характер решений Конституционного Суда Российской Федерации // Журнал российского права. 2004. № 12. С. 3-9 ; Бондарь С. Н. Конвенционная юрисдикция Европейского суда по правам человека в соотношении с компетенцией Конституционного Суда РФ // Там же. 2006. № 6. С. 113-127 ; Эбзеев Б. С. Глобализация, Европейский консенсус и рецепция Россией европейских гуманитарных стандартов : механизмы и пределы // Актуальные проблемы теории и практики конституционного судопроизводства : сб. науч. трудов. Казань, 2007. Вып. 2. С. 57-81.

${ }^{6}$ См.: Зорькин В. Д. На вершине судебной власти. С. 18 ; Диалог Конституционного суда Российской Федерации и Европейского суда по правам человека в контексте конституционного правопорядка : доклад на XIII Междунар. форуме по конституционному правосудию (СПб., 18-20 ноября 2010 г.). URL: http:// www.ksrf.ru/ru/News/Speech/Pages/ViewItem.aspx?ParamId=39 (дата обращения:

250 03.11.2020).

${ }^{7}$ См.: Зорькин В. Д. Право метамодерна : постановка проблемы : лекция на IX Петербургском Междунар. юрид. форуме (СПб., 16 мая 2019 г.) // Рос. газета. URL: https://rg.ru/2019/05/16/zorkin-priverzhennost-vernoj-filosofii-prava-pozvoliaettvorit-dobro.html (дата обращения: 03.11.2020) ; Овчинникова Н. О. Использование решений ЕСПЧ в уголовно-процессуальном доказывании (г. Саратов, 3 апреля 2020 г.) // Доказательства и доказывание в уголовном судопроизводстве : история, современность и перспективы развития (к 95-летию со дня рождения Ц. М. Каз) : материалы Междунар. науч.-практ. конф. Саратов, 2020. C. $105-107$.

${ }^{8}$ По делу о проверке конституционности положений статьи 1 Федерального закона «О ратификации Конвенции о защите прав человека и основных свобод и Протоколов к ней», пунктов 1 и 2 статьи 32 Федерального закона «О международных договорах Российской Федерации», частей первой и четвертой статьи 11 , 
жет считаться обязательным для исполнения, если толкование положений Конвенции приводит к их расхождению с Конституцией РФ, нарушая тем самым принцип суверенного равенства и принцип невмешательства во внутренние дела государств ${ }^{9}$. Так, на основании приведенных положений в постановлении от 19 апреля 2016 г. № 12-П Конституционный Суд РФ принял решение о невозможности исполнения постановления ЕСПЧ от 4 июля 2013 г. по делу “Анчугов и Гладков против России» ${ }^{10}$.

Более того, внесенные в 2020 г. в Конституцию РФ изменения возвели указанное выше полномочие Конституционного Суда РФ в ранг нормоположения Основного закона страны. Согласно п. «б» ч. 5.1 ст. 125 Конституции РФ Конституционный Суд РФ «...в порядке, установленном федеральным конституционным законом, разрешает вопрос о возможности исполнения решений межгосударственных органов, принятых на основании положений международных договоров Российской Федерации в их истолковании, противоречащем Конституции Российской Федерации, а также о возможности исполнения решения иностранного или международного (межгосударственного) суда, иностранного или международного третейского суда (арбитража), налагающего обязанности на Российскую Федерацию, в случае если это решение противоречит основам публичного правопорядка Российской Федерации» ${ }^{11}$.

Помимо указанных полномочий в законопроекте «О внесении изменений в Федеральный конституционный закон «О Конституционном Суде Российской Федерации» предлагается новое условие допустимости жалобы в Конституционный Суд РФ. Теперь в предмет рассмотрения Конституционного Суда РФ будут входить жалобы граждан, права и свободы которых нарушены нормами, примененными в конкретном уголовном деле, если исчерпаны все другие внутригосударственные средства судеб-

пункта 4 части четвертой статьи 392 Гражданского процессуального кодекса Российской Федерации, частей 1 и 4 статьи 13, пункта 4 части 3 статьи 311 Арбитражного процессуального кодекса Российской Федерации, частей 1 и 4 статьи 15, пункта 4 части 1 статьи 350 Кодекса административного судопроизводства Российской Федерации и пункта 2 части четвертой статьи 413 Уголовно-процессуального кодекса Российской Федерации в связи с запросом группы депутатов Государственной Думы : постановление Конституционного Суда РФ от 14 июля 2015 г. № 21-П // Вестник Конституционного Суда РФ. 2015. № 6.

${ }^{9} \mathrm{O}$ внесении изменений в Федеральный конституционный закон «О Конституционном Суде Российской Федерации» : федер. конституц. закон от 14 декабря 2015 г. № 7-ФКЗ // Собр. законодательства Рос. Федерации. 2015. № 51 (ч. 1). Ст. 7229.

${ }^{10}$ По делу о разрешении вопроса о возможности исполнения в соответствии с Конституцией Российской Федерации постановления Европейского суда по правам человека от 4 июля 2013 года по делу “Анчугов и Гладков против России» в связи с запросом Министерства юстиции Российской Федерации : постановление Конституционного Суда РФ от 19 апреля 2016 г. № 12-П // Собр. законодательства Рос. Федерации. 2016. № 17. Ст. 2480.

${ }^{11}$ Конституция Российской Федерации : принята всенародным голосованием 12 декабря 1993 г. // Рос. газета. 1993. 25 дек. ; 2020. 16 марта. 


\section{Вестник ВГУ. Серия: Право}

ной защиты. Обратиться в Конституционный Суд РФ смогут граждане и юридические лица, если они считают, что их конституционные права и свободы нарушены следующими документами, примененными в конкретном деле: федеральным конституционным законом или федеральным законом; нормативным актом Президента, Правительства, Совета Федерации, Государственной Думы; региональным нормативным актом, который издан по вопросам ведения Российской Федерации, а также совместного ведения Российской Федерации и региона ${ }^{12}$. Это означает, что теперь участникам уголовного судопроизводства, чьи права и интересы были нарушены в ходе производства по делу, пройдя процедуру апелляционного, кассационного и надзорного обжалования, необходимо будет сначала обратиться за защитой своих прав в Конституционный Суд РФ, а только потом станет возможным обращение в ЕСПЧ.

С одной стороны, это дополнительная гарантия соблюдения прав участников уголовного процесса органами и должностными лицами, ведущими производство по делу, а с другой - если Конституционный Суд РФ, рассмотрев указанную жалобу, придет к выводу, что она не подлежит удовлетворению, то это автоматически делает бессмысленным последующее обращение в ЕСПЧ с этой же жалобой, поскольку Конституционный Суд РФ уже высказал по ней свою правовую позицию, а противоречащее ей решение ЕСПЧ соответственно будет признано неисполнимым.

Представляется, что Конституционный Суд РФ является ключевым звеном в реализации решений ЕСПЧ в сфере российского уголовного судопроизводства. Его решения не признаются источником уголовно-процессуального права, но фактически являются таковыми ${ }^{13}$. Речь идет о судебном нормотворчестве в деятельности Конституционного Суда РФ $\Phi^{14}$. Признавая норму уголовно-процессуального права не соответствую-

- щей Конституции РФ путем ссылки в своем постановлении на решения 을 ЕСПЧ, Конституционный Суд РФ «переносит» правовое регулирование, установленное ЕСПЧ, в своем решении в конституционную судебную

$12 \mathrm{O}$ внесении изменений в Федеральный конституционный закон «О Конституционном Суде Российской Федерации» : проект федерального конституционного закона № 1024643-7. URL: https://sozd.duma.gov.ru/bill/1024643-7\#utm_ campaign=nw\&utm_source=consultant\&utm_medium=email\&utm_content=old (дата обращения: 05.11.2020).

${ }^{13}$ См.: Митюков М. А., Барнашов А. М. Очерки конституционного правосудия (сравнительно-правовое исследование законодательства и судебной практики). Томск, 1999 ; Свечникова Н. В. Решения Конституционного Суда Российской Федерации как источник конституционного права : авторедр. дис. ... канд. юрид. наук. М., 2004 ; Зорькин В. Д. Прецедентный характер решений Конституционного Суда Российской Федерации. С. 3-9 ; Гаджиев Г. А. Феномен судебного прецедента в России // Судебная практика как источник права. М., 2000. С. 98-106.

${ }^{14}$ См.: Овчинникова Н. О. Фактическая правотворческая деятельность Конституционного Суда Российской Федерации - способ устранения пробелов в уголовно-процессуальном праве России // Вестник Саратовской гос. юрид. академии. 2018. № 5. C. 247-254. 
норму, а затем данная норма подлежит включению в уголовно-процессуальное законодательство посредством нормотворчества ${ }^{15}$.

Примерами прохождения такого пути от решения ЕСПЧ до нормы внутригосударственного законодательства являются законодательные изменения, направленные на исполнение постановлений по делу «Бурдов (Burdov) против Российской Федерации» ${ }^{16}$, «Беднов (Bednov) против Российской Федерации» ${ }^{17}$ и «Тимофреeв (Timofeyev) против Российской Федерации» ${ }^{18}$.

15 По делу о проверке конституционности положений частей второй и восьмой статьи 56, части второй статьи 278 и главы 40.1 Уголовно-процессуального кодекса Российской Федерации в связи с жалобой гражданина Д. В. Усенко : постановление Конституционного Суда РФ от 20 июля 2016 г. № 17-П // Собр. законодательства Рос. Федерации. 2016. № 31. Ст. 5088 ; По делу о проверке конституционности пункта 7 части второй статьи 29 , части четвертой статьи 165 и части первой статьи 182 Уголовно-процессуального кодекса Российской Федерации в связи с жалобой граждан А. В. Баляна, М. С. Дзюбы и других : постановление Конституционного Суда РФ от 17 декабря 2015 г. № 33-П // Вестник Конституционного Суда РФ. 2016. № 2 ; По жалобе гражданина Петрова Максима Владимировича на нарушение его конституционных прав частью первой и подпунктом «б» пункта 2 части четвертой статьи 413, частью пятой статьи 415 Уголовно-процессуального кодекса Российской Федерации : определение Конституционного Суда РФ от 14 января 2016 г. № 13-О // Там же. № 3.

16 Дело «Бурдов (Burdov) против Российской Федерации» (№ 2) (жалоба № 33509/04) : постановление ЕСПЧ от 15 января 2009 г. // Российская хроника Европейского суда. 2009. № 4.

${ }^{17}$ Дело «Беднов (Bednov) против Российской Федерации» (жалоба № 21153/02). URL: http://docs.cntd.ru/document/902156440 (дата обращения: 13.08.2019) ; Дело «Игнатов (Ignatov) против Российской Федерации» (жалоба № 27193/02). URL: http://www.consultant.ru/cons/cgi/online.cgi\%3Freq\%3Ddoc\%3Bbase\%3DARB\%3B $\mathrm{n} \% 3 \mathrm{D} 435688$ req $=$ doc $\&$ base $=\mathrm{ARB} \& \mathrm{n}=42822 \& \mathrm{dst}=100188 \# 046669908571027996$ (дата обращения: 13.08.2019).

18 Дело «Тимодеeв (Timofeyev) против Российской Федерации» (жалоба № 16887/07) // Официальный сайт Министерства юстиции PФ. URL: https:// minjust.ru/ru/2018-god/delo-timofeev-protiv-rossii (дата обращения: 13.08.2019) ; О компенсации за нарушение права на судопроизводство в разумный срок или права на исполнение судебного акта в разумный срок : федер. закон от 30 апреля 2010 г. № 68-Ф3 // Собр. законодательства Рос. Федерации. 2010. № 18. Ст. 2144 ; О внесении изменений в отдельные законодательные акты Российской Федерации в связи с принятием Федерального закона «О компенсации за нарушение права на судопроизводство в разумный срок или права на исполнение судебного акта в разумный срок» : фредер. закон от 30 апреля 2010 г. № 69-ФЗ // Там же. Ст. 2145 ; О внесении изменений в Уголовно-процессуальный кодекс Российской Федерации : федер. закон от 30 декабря 2015 г. № 437-ФЗ // Там же. № 1 (ч. 1). Ст. 57 ; О некоторых вопросах, возникающих при рассмотрении дел о присуждении компенсации за нарушение права на судопроизводство в разумный срок или права на исполнение судебного акта в разумный срок : постановление Пленума Верховного Суда РФ от 29 марта 2016 г. № 11 // Бюллетень Верховного Суда РФ. 2016. № 5 ; Совет Европы отметил реформирование законодательства РФ с учетом практики ЕСПЧ // Официальный сайт РАПСИ. URL: http://rapsinews.ru/ international_news/20171107/280848488.html (дата обращения : 13.08.2019). 
Для обеспечения реализации прав подозреваемых (обвиняемых) на обращение в ЕСПЧ с учетом выводов Европейского суда, изложенных в постановлении по делу «Захаркин (Zakharkin) против Российской Федерации» ${ }^{19}$, принят Федеральный закон от 28 июня 2014 г. № 193-Ф3 ${ }^{20}$. На стадии подготовки находятся законопроекты, направленные на исполнение решений ЕСПЧ по делам «Ефимова (Yefimova) против Российской Федерации» ${ }^{21}$, «Матыцина (Matytsina) против Российской Федерации» ${ }^{22}$, «Царенко (Tsarenko) против Российской Федерации» ${ }^{23}$.

Использование решений ЕСПЧ национальными судами при разрешении конкретных уголовных дел не запрещается а, наоборот, приветствуется. Так, в постановлении от 27 июня 2013 г. № 21 Пленум Верховного Суда РФ ориентирует суды на общеобязательность правовых позиций ЕСПЧ, содержащихся в его окончательных постановлениях, принятых в отношении Российской Федерации ${ }^{24}$. Более того, Верховный Суд РФ указал на необходимость учитывать правовые позиции ЕСПЧ, изложенные в постановлениях, вынесенных в отношении других государств - участников Конвенции, если обстоятельства рассматриваемого ими дела аналогичны обстоятельствам, ставшим предметом рассмотрения в ЕСПЧ ${ }^{25}$.

Безусловно, в рамках российской правовой системы прецедентный характер решений ЕСПЧ не позволяет считать их источником уголовно-процессуального права и источником российского права в целом. Поэтому указанные решения, если они не были имплементированы в

19 Дело «Захаркин (Zakharkin) против Российской Федерации» (жалоба № 1555/04) : постановление ЕСПЧ от 10 июня 2010 г. // Бюллетень Европейского суда по правам человека. 2011. № 2.

${ }^{20} \mathrm{O}$ внесении изменения в статью 18 Федерального закона «О содержании под стражей подозреваемых и обвиняемых в совершении преступлений» : фредер. закон от 28 июня 2014 г. № 193-ФЗ // Собр. законодательства Рос. Федерации. 2014. № 26 (ч. 1). Ст. 3399.

21 Дело «Ефимова (Yefimova) против Российской Федерации» (жалоба № 39786/09) : постановление ЕСПЧ от 19 февраля 2013 г. // Бюллетень Европейского суда по правам человека. 2014. № 1 .

22 Дело «Матыцина (Matytsina) против Российской Федерации» (жалоба № 58428/10) : постановление ЕСПЧ от 27 марта 2014 г. // Прецеденты Европей-

254 ского суда по правам человека. 2014. № 4 (04).

23 Дело «Царенко (Tsarenko) против Российской Федерации» (жалоба № 5235/09) : постановление ЕСПЧ от 3 марта 2011 г. // Бюллетень Европейского суда по правам человека. 2012. № 4.

${ }^{24}$ Пункты 2 и 3 постановления Пленума Верховного Суда РФ от 27 июня 2013 г. № 21 «О применении судами общей юрисдикции Конвенции о защите прав человека и основных свобод от 4 ноября 1950 года и Протоколов к ней» // Бюллетень Верховного Суда РФ. 2013. № 8.

${ }^{25}$ Там же. См. также: Султанов А. Р. К 15-летнему юбилею действия для России Европейской конвенции о защите прав человека и основных свобод от 4 ноября 1950 года // Вестник гражданского процесса. 2013. № 4. С. 289-290 ; Бурлагин С. В. Проблемы применения решений Европейского суда по правам человека при рассмотрении уголовных дел судами Российской Федерации // Всероссийский криминологический журнал. 2018. Т. 12, № 2. С. 299-309. 
российское уголовно-процессуальное законодательство, в правоприменительной деятельности могут иметь либо преюдициальное значение, либо использоваться как основание для возбуждения производства ввиду новых или вновь открывшихся обстоятельств по правилам ч. 5 ст. 415 УПК РФ $\Phi^{26}$.

Таким образом, место и роль решений ЕСПЧ в механизме удаления пробелов в уголовно-процессуальном праве России определяется следующими формулами:

- постановление ЕСПЧ против России $\rightarrow$ постановление Конституционного Суда РФ, основанное на правовой позиции ЕСПЧ $\rightarrow$ нормотворчество $\rightarrow$ устранение пробела;

- постановление ЕСПЧ против России $\rightarrow$ постановление Пленума Верховного Суда РФ $\rightarrow$ применение правовых позиций ЕСПЧ судом при разрешении конкретного уголовного дела $\rightarrow$ преодоление пробела.

Приведенные формулы требуют некоторых разъяснений:

1. Решения ЕСПЧ носят прецедентный характер и не могут быть включены в систему источников уголовно-процессуального права, а следовательно, устранять пробелы внутринационального законодательства путем их простого исполнения (непосредственно) без прохождения процедуры имплементации правовых позиций ЕСПЧ.

2. Решения ЕСПЧ обязательны для исполнения, за исключением случаев, когда в результате толкования конкретное положение Конвенции о защите прав человека и основных свобод расходится с императивными нормами общего международного права, к числу которых относятся принцип суверенного равенства и уважения прав, присущих суверенитету, а также принцип невмешательства во внутренние дела государств.

3. Ключевым звеном в устранении пробелов на основании решений ЕСПЧ в сфере российского уголовного судопроизводства является Конституционный Суд РФ. Он, признавая норму уголовно-процессуального права не соответствующей Конституции РФ, путем ссылки в своем постановлении на решения ЕСПЧ «переносит» правовое регулирование, установленное ЕСПЧ в своем решении в конституционную судебную норму, а затем данная норма подлежит включению в уголовно-процессуальное законодательство посредством нормотворчества.

4. Решения ЕСПЧ участвуют в преодолении пробелов уголовно-процессуального права непосредственно в том случае, когда его позиции восприняты Верховным Судом РФ, и национальные суды ссылаются на конкретные решения ЕСПЧ при мотивировке решения по уголовному делу.

5. Изменения, связанные с расширением предмета рассмотрения Конституционного Суда РФ, наделением его статусом конечного звена

${ }^{26}$ См.: Овчинникова Н. О. Использование решений ЕСПЧ в уголовно-процессуальном доказывании // Доказательства и доказывание в уголовном судопроизводстве : история, современность и перспективы развития (к 95-летию со дня рождения Ц. М. Каз) : материалы Междунар. науч.-практ. конф. (г. Саратов, 3 апреля 2020 г.). Саратов, 2020. С. 105-107. 
судебной системы, осуществляющей судебный контроль, повышают гарантии соблюдения прав участников уголовного процесса, но в то же время могут привести к бессмысленности обращения участников уголовного судопроизводства в ЕСПЧ за защитой своих прав.

\footnotetext{
Саратовская государственная юри- Saratov State Academy of Law дическая академия

Ovchinnikova N. O., Candidate of Legal

Овчинникова Н. О., кандидат юридический наук, доцент кафедры уголовного проиесса

E-mail: natalya-afonina@list.ru Sciences, Associate Professor of the Criminal Process Department

E-mail: natalya-afonina@list.ru
} 